\section{Sexual abuse and alcohol use among women in metropolitan São Paulo, Brazil: a general population study}

\section{Abuso sexual e uso de álcool entre mulheres na região metropolitana de São Paulo, Brasil: um estudo em população geral}

\author{
Janaina Barbosa de Oliveira' \\ Florence Kerr-Corrêa" \\ Maria Cristina Pereira Lima" \\ José Manoel Bertolote" \\ Adriana Marcassa Tucci"'I
}

'Center for Health and Education Studies, School of Sciences and Philosophy, Universidade Estadual Paulista "Júlio de Mesquita Filho" - Marília (SP), Brazil.

"Neurology, Psychology and Psychiatry Department, Botucatu Medical School, Universidade Estadual Paulista "Júlio de Mesquita Filho" - Botucatu (SP), Brazil.

"'Health, Education and Society Department, Universidade Federal de

São Paulo - Santos (SP), Brazil.

Corresponding author: Janaina Barbosa de Oliveira. Centro de Estudos da Educação e da Saúde Universidade Estadual Paulista, Avenida Vicente Ferreira, 1.278, CEP: 17515-000, Marília, SP, Brazil. E-mail: janaina.btu@gmail.com

Source of funding: Fundação de Amparo à Pesquisa do Estado de São Paulo (FAPESP 04/11729-2).

Conflict of interests: nothing to declare.

\section{Abstract}

Objective: The present study aimed at estimating the prevalence of lifetime sexual abuse among women and at investigating its association with alcohol consumption. Method: Population-based survey conducted through a representative and stratified cluster sample of metropolitan São Paulo. GENACIS questionnaire was used. Sample unit was the home, and all residents aged 18 years and over were interviewed. The outcome was lifetime sexual abuse. The univariate statistical analysis used the Rao-Scott test. Logistic regression was used for the multivariate analysis. Results: The final sample totalized 1,216 women aged 18 years and over; the response rate was $75.0 \%$. Most women were married $(56.6 \%)$ and had less than 12 years of formal education (59.0\%); $46.2 \%$ were aged between 25 and 44 years, and $44.4 \%$ had a low income. Of the respondents, $7.5 \%$ reported having suffered lifetime sexual abuse. Multiple logistic regression model showed an association between lifetime sexual abuse and being a heavy drinker $(\mathrm{OR}=4.97)$ and being a former drinker $(\mathrm{OR}=2.04)$. Conclusions: There are few population studies in Brazil investigating sexual abuse and its relation to alcohol use. Although the prevalence of lifetime sexual abuse in the present study was smaller than that observed in other studies, it is a highly expressive percentage on account of its social and economic impact, as well as its potential effect on the health system.

Keywords: Sexual violence. Alcoholic beverages. Women. Cross-sectional survey. Brazil. 


\section{Resumo}

Objetivo: $\mathrm{O}$ presente estudo teve como objetivo estimar a prevalência de abuso sexual durante a vida entre as mulheres e investigar sua associação com o consumo de álcool. Método: Estudo de base populacional realizado por meio de uma amostra representativa e estratificada por conglomerados da região metropolitana de São Paulo. Foi utilizado o questionário GENACIS. A unidade amostral foi a residência, e todos os moradores com 18 anos ou mais foram entrevistados. O desfecho foi abuso sexual durante a vida. Foi utilizado o teste de Rao-Scott para análise estatística univariada. Foi utilizada a regressão logística para a análise multivariada. Resultados: A amostra final totalizou 1.216 mulheres com 18 anos ou mais, a taxa de resposta foi de $75,0 \%$. A maioria das mulheres era casada $(56,6 \%)$ e tinha menos de 12 anos de educação formal (59,0\%), 46,2\% tinham entre 25 e 44 anos e $44,4 \%$ tinham uma renda baixa. Dos entrevistados, $7,5 \%$ relataram ter sofrido abuso sexual durante a vida. O modelo de regressão logística múltipla mostrou associação entre abuso sexual durante a vida e ser bebedor pesado $(\mathrm{OR}=4,97)$ e ser ex-bebedor $(\mathrm{OR}=2,04)$. Conclusões: Existem poucos estudos populacionais no Brasil que investigam abuso sexual e sua relação com o uso deálcool.Embora a prevalência de abuso sexual durante a vida no presente estudo tenha sido menor que a observada em outros trabalhos, é um percentual muito expressivo em razão de seu impacto social e econômico, bem como seu potencial efeito sobre o sistema de saúde.

Palavras-chave: Violência sexual. Bebidas alcoólicas. Mulheres. Estudo populacional. Brasil.

\section{Introduction}

Sexual abuse can be regarded as shaped by socioeconomic variables, gender roles and the normative acceptance of aggression that are characteristic of a given society ${ }^{1}$. Sexual violence refers to the use or threat of physical violence or the exploitation of a partner's inability to offer resistance to force her or him to engage in sexual acts. More broadly, sexual aggression includes all behaviours carried out with the intention of forcing someone to engage in sexual activity against her or his will ${ }^{2}$. Previous research indicates that women are more likely to be victims of sexual assault ${ }^{3}$. Even in studies on sexually abused children and adolescents, most victims were females ${ }^{4}$. Bassani et $\mathrm{al}^{5}$. have estimated lifetime prevalence of child sexual abuse in a Brazilian urban sample; people who took part in this research were 14 years old and over and reported 5.6 and $1.6 \%$ of lifetime sexual abuse for girls and boys respectively. A review of population-based surveys showed that 10 to $69 \%$ of women indicated having been at some time a target of physical aggression at the hands of their partners, of which one third to half of cases by sexual violence ${ }^{6}$.

Data on prevalence of sexual abuse must be analyzed cautiously, given that underreporting is frequent ${ }^{7}$. When it occurs in the domestic environment, such abuse becomes relatively "invisible", since it is not always perceived or experienced by the victim as being violence, but rather is "legitimized" by conjugal union. One studied carried out in the countryside of São Paulo state indicated that $54.8 \%$ of the women interviewed reported having had sexual relations at some time against their will ${ }^{8}$. Factors such as fear of the aggressor and shame of the family and of society lead to a situation in which many women neglect to denounce their aggressors and, when they do so, many desist before bringing forward the complaint ${ }^{9}$.

The consumption of alcoholic beverages is frequently considered an important factor associated with sexual violence, allied with the personality characteristics of the aggressor, 
since it favours the pursuit of immediate pleasure and total disregard for social approval. Zilberman and Blume ${ }^{10}$ described that psychoactive substances are involved in as many as $92 \%$ of episodes registered as domestic violence, with alcohol being present in up to $50 \%$ of sexual aggression cases.

Several studies point as the main risk factors to be a victim of sexual abuse: beingyoung, low level of education, financial dependence, unemployment, having witnessed or suffered abuse in the family of origin ${ }^{2}$, having suffered child abuse ${ }^{11}$ and alcohol consumption by intimate partner ${ }^{12}$.

On the other hand, studies on the prevalence of sexual abuse provide conflicting data due to different models of research methodology employed and the diverse concepts used to define sexual abuse ${ }^{13}$.

Sexual abuse is linked to several psychiatric consequences, with greater risk of depression $^{14}$, conduct and personality disorders ${ }^{16}$, disruption of sexual preference, substance abuse, as well as sexually aggressive ${ }^{16}$ and suicidal behaviours ${ }^{17}$. Women suffering sexual violence were 2.5 times more likely to report post-traumatic stress disorder symptoms compared to those who experienced physical (non sexual) violence ${ }^{18}$. Furthermore, the sexual aggressors present a six-fold greater risk of having been sexually victimized during childhood ${ }^{13}$.

This paper is part of the GENACIS Project (Gender, Alcohol and Culture: An International Study), a cross-sectional study carried out in different countries to investigate alcohol use between genders and associated violence. It was supported by Pan American Health Organization (PAHO) and was conducted in 2005 - 2006. The present study aimed to estimate the prevalence of lifetime sexual abuse among women, investigating its association with self-reported alcohol use.

\section{Methods}

This is a cross-sectional population-based survey carried out in metropolitan São Paulo, which comprises 39 cities and towns. The Brazilian Institute of Geography and
Statistics (IBGE) estimated the population in that metropolitan area as approximately $19,037,000$ inhabitants, about two thirds of the population of São Paulo state.

\section{Sample}

It was a multistage cluster sample design with proportional size probability. The sample was representative of socioeconomic and educational levels, and it was drawn from São Paulo metropolitan area. The subjects of this study were female, residents of randomly chosen households aged 18 years and more, who consented to provide the information. Each stratum was based on the census sector according Brazilian Institute of Geography and Statistics. The sampling unit was family households. The sample size was increased to allow for a possible non-response rate of $20 \%$. The sample weight was adopted to adjust to the sample design and they represent the inverse of the unit's probability of selection.

\section{Procedures}

Face-to-face interviews were conducted in the households by trained interviewers. They were given advanced training on the GENACIS questionnaire, which included specific information on alcohol and drinking behaviour (e.g., antecedents and consequences, problematic behaviour, heavy drinking), violence and sexual abuse. The interviewers also received training for inquire about sexual abuse in a supportive way. They had address of the support services on the household area. Privacy was guaranteed for the interviewed, and monthly supervisions were provided for support the interviewers. Previous to the interviews, letters were sent to the selected households informing them of the study objectives, methodology, its results in several other countries and the importance of their contribution. Interviewers wore lab coats, carried identification badges and booked appointments in advance. For qualitative control, $10 \%$ of respondents were contacted and invited to respond again part of the questionnaire. In order to reverse refusals, letters expressing the objectives, importance 
and expected impact of the study, besides providing the credentials and contact information of the main investigators, were sent to those who had refused to participate on the first attempt. The website address of the project (www.viverbem.fmb.unesp.br/pesquisa) was also included whereby study subjects could obtain detailed information on it.

\section{Instruments}

The GENACIS questionnaire (available upon request) was developed by an international group of investigators who were interested in comparing drinking patterns between genders in different contexts and cultures. The version used in this study consists of an ample questionnaire that includes questions on demographics characteristics, detailed alcohol consumption and sexual abuse, among others. The questionnaire, translated into Brazilian Portuguese, had been used in previous studies ${ }^{19}$.

All alcohol consumption was standardized as drinks containing 13 grams of ethanol. Respondents who reported not drinking in the past year were divided into: "lifetime abstainers" - those not drinking at any point in their lives, and "former drinkers" - who reported not drinking at all in the past year, but had drunk previously any amount. Drinkers were divide regarding their average alcohol use in the previous year in three levels: who those drunk one or two drinks per day, three or four drinks per day and five or more drinks per day. All categories were mutually exclusive.

The questions about sexual abuse investigated its occurrence and the age when it happened. Only if the sexual abuse took place before the victim was 16 years old was it asked whether the aggressor was a family member. All positive answers about sexual abuse were aggregated into the variable "lifetime sexual abuse". Common mental disorder was assessed using the Self Report Questionnaire (SRQ-20), an instrument with 20 yes-no questions. The SRQ-20 was designed by The World Health Organization, validated in Brazil by Mari and Williams ${ }^{19}$. A score above 5 for men and above 7 for women was defined as indicating presence of common mental disorder.

\section{Statistical analyses}

The dependent variable was having suffered sexual abuse throughout the respondent's life. The categories of sexual abuse described in Table 1 were grouped into "lifetime sexual abuse" due to small numbers of responses, which would diminish the power of analyzes. The main explanatory variable was alcohol use. The association between lifetime sexual abuse and explanatory variables was investigated by the Rao-Scott test ${ }^{21}$. Stepwise-type logistic regression analyses was accomplished, including variables that showed association with sexual abuse throughout life with $\mathrm{p} \leq$ 0.15 . All analyses were conducted utilizing the software Stata 10.0. Statistical significance was concluded for $p$-values $\leq 0.05$ in the Wald test with respective confidence interval of $95 \%$. The analyses were weighted to adjust for sample design.

\section{Ethical considerations}

The Research Ethics Committee of the Botucatu Medical School, Universidade Estadual Paulista "Júlio de Mesquita Filho", approved this project on September 13, 2004. The participants were included only after obtaining written informed consent, and they were reassured that the questionnaire would not be connected to their names. Interviewers always carried a questionnaire-wildcard case to fellow attacker appeared during the interview. Handouts and addresses of local aid to victims of domestic violence were delivered to the participants when necessary.

\section{Results}

The response rate was $75.0 \%$. In the sample, 86 women reported sexual abuse at the lifetime $(7.5 \%, 95 \%$ CI $5.3-7.6)$. It was asked when the sexual abuse was occurred and, among those who reported before 16 years old, it was 
also asked who the aggressor was (Table 1). The prevalence of sexual abuse before 16 years old whose perpetrator was someone in the family was $3.4 \%$, and with a perpetrator other than family was $4.5 \%$. Among those who had a sexual abuse after 16 years old, the prevalence was $2.9 \%$.

Table 2 also shows the prevalence of lifetime sexual abuse for each demographic variable. The prevalence was $7.5 \%$ for the whole sample and it was associated only with income $(p=0.03)$, among the demographic characteristics investigated.

The Table 3 shows alcohol use, intimate partner violence, common mental disorder, and the prevalence of lifetime sexual abuse for these variables. The largest category was lifetime abstainers (47.5\%), followed by former drinkers $(22.2 \%)$ and by those who had drunk 1 or 2 drinks on average (20.5\%). The prevalence of intimate partner violence was $5.8 \%$ for those who were aggressors and $4.7 \%$ for those who were victims. Common mental disorder was found in $28.1 \%$ of the sample. Lifetime sexual abuse was associated with alcohol use ( $\mathrm{p}=0.01)$, having committed a violence against intimate partner
( $\mathrm{p} \leq 0.001$ ), and thepresence ofacommonmental disorder $(\mathrm{p}=0.03)$. Being a victim of intimate partner violence was not associated with lifetime sexual abuse $(\mathrm{p}=0.08)$.

Results of the multiple logistic regression model for lifetime sexual abuse are presented in Table 4. All variables who reached $\mathrm{p} \leq 0.15$ in the univariate analyses were included in the logistic regression model. They are: alcohol use, income, being aggressor and being a victim in intimate partner violence, and education. The reference category was lifetime abstainers. At the final model, just alcohol use showed associations with lifetime sexual abuse. Higher risks were observed for those who drunk five or more drinks on average $(\mathrm{OR}=4.97)$ and former drinkers $(\mathrm{OR}=2.04)$. There was a tendency toward higher risk in those who drunk three or four drinks on average $(\mathrm{p}=0.18)$.

We also tested the average of alcohol consumed (grams per day); for those who had lifetime sexual abuse was $7.83 \mathrm{~g}$, and for those who did not report lifetime sexual abuse was $3.94 \mathrm{~g}$. (results not shown). The $t$-test adjusted for unequal variance showed no statistically significant difference $(\mathrm{p}=0.10)$.

Table 1 - Frequency of sexual abuse among women, metropolitan São Paulo, Brazil.

Tabela 1 - Frequência de abuso sexual entre mulheres, região metropolitana de São Paulo, Brasil.

\begin{tabular}{|c|c|c|}
\hline & $\mathrm{n}$ & $\%^{*}$ \\
\hline \multirow{2}{*}{\multicolumn{3}{|c|}{$\begin{array}{l}\text { Before you were } 16 \text { years old (age } 15 \text { or younger), did someone in your family try to make you do sexual } \\
\text { things or watch sexual things?** }\end{array}$}} \\
\hline & & \\
\hline Never & 1.183 & 97.6 \\
\hline Rarely & 11 & 0.8 \\
\hline Sometimes & 9 & 0.9 \\
\hline Often & 3 & 0.4 \\
\hline Very often & 2 & 0.3 \\
\hline \multirow{2}{*}{\multicolumn{3}{|c|}{$\begin{array}{l}\text { Before you were } 16 \text { years old (age } 15 \text { or younger), did someone other than a family member try } \\
\text { to make you do sexual things or watch sexual things?** }\end{array}$}} \\
\hline & & \\
\hline Never & 1.156 & 95.4 \\
\hline Rarely & 41 & 3.6 \\
\hline Sometimes & 7 & 0.9 \\
\hline Often & 2 & 0.1 \\
\hline Very often & 2 & 0.1 \\
\hline \multirow{2}{*}{\multicolumn{3}{|c|}{$\begin{array}{l}\text { Since the age of } 16 \text { ( } 16 \text { or older), was there a time when someone forced you to have sexual activity } \\
\text { that you really did not want? }\end{array}$}} \\
\hline & & \\
\hline Yes & 32 & 2.9 \\
\hline No & 1.180 & 97.1 \\
\hline
\end{tabular}

*Weighted for sampling design. **No information for eight subjects.

*Percentuais corrigidos para desenho amostral. **Sem informação de oito sujeitos. 
Table 2 - Lifetime sexual abuse prevalence according to demographic characteristics among female in the population sample, metropolitan São Paulo, Brazil.

Tabela 2 - Prevalência de abuso sexual durante a vida de acordo com características demográficas entre mulheres, região metropolitana de São Paulo, Brasil.

\begin{tabular}{|c|c|c|c|c|c|}
\hline & & & & $\begin{array}{l}\text { e sexu } \\
=86(7\end{array}$ & \\
\hline & $\mathrm{n}$ & $\% *$ & $\mathrm{n}$ & $\%^{*}$ & $p$-value \\
\hline Age $^{* *}$ & & & & & 0.54 \\
\hline 18 to 24 & 194 & 18.0 & 12 & 5.7 & \\
\hline 25 to 34 & 260 & 24.2 & 21 & 8.1 & \\
\hline 35 to 44 & 239 & 22.0 & 20 & 9.3 & \\
\hline 45 to 54 & 182 & 15.1 & 14 & 8.8 & \\
\hline 55 to 64 & 160 & 11.2 & 10 & 6.2 & \\
\hline$\geq 65$ & 180 & 9.5 & 9 & 4.3 & \\
\hline Marital status & & & & & 0.61 \\
\hline Married & 663 & 56.6 & 45 & 7.3 & \\
\hline Widowed & 157 & 9.2 & 9 & 4.8 & \\
\hline Divorced & 103 & 8.1 & 9 & 10.4 & \\
\hline Single & 293 & 25.1 & 23 & 7.8 & \\
\hline Education** & & & & & 0.13 \\
\hline Illiterate & 76 & 5.0 & 1 & 0,9 & \\
\hline Incomplete high school & 667 & 54.0 & 48 & 9.0 & \\
\hline High school or more & 472 & 41.0 & 37 & 6.2 & \\
\hline Income per capita in dollars & & & & & 0.03 \\
\hline 0 to 75 & 484 & 44.3 & 34 & 7.9 & \\
\hline 76 to 150 & 260 & 20.0 & 20 & 8.0 & \\
\hline 151 to 300 & 250 & 18.6 & 6 & 2.2 & \\
\hline$\geq 301$ & 222 & 17.1 & 26 & 11.6 & \\
\hline
\end{tabular}

*Weighted for sampling design. **No information for one subject.

*Percentuais corrigidos para desenho amostral. **Sem informação de um sujeito.

Table 3 - Lifetime sexual abuse prevalence according selected variables among female in the population sample, metropolitan São Paulo, Brazil.

Tabela 3 - Prevalência de abuso sexual durante a vida de acordo com variáveis selecionadas na amostra populacional, região metropolitana de São Paulo, Brasil.

\begin{tabular}{|c|c|c|c|c|c|}
\hline & \multicolumn{2}{|c|}{$\begin{array}{c}\text { Total } \\
\mathrm{n}=1,216\end{array}$} & \multicolumn{3}{|c|}{$\begin{array}{l}\text { Lifetime sexual abuse } \\
\qquad \mathrm{n}=86(7.5 \%)\end{array}$} \\
\hline & $\mathrm{n}$ & $\%$ & $\mathrm{n}$ & $\% *$ & $\mathrm{p}$-value \\
\hline Alcohol use & & & & & 0.01 \\
\hline Lifetime abstainer & 618 & 47.5 & 31 & 4.9 & \\
\hline $1-2$ drinks & 253 & 20.5 & 18 & 7.7 & \\
\hline $3-4$ drinks & 73 & 5.9 & 6 & 11.1 & \\
\hline 5 drinks or more & 44 & 3.9 & 7 & 20.1 & \\
\hline Former drinkers & 228 & 22.2 & 24 & 9.5 & \\
\hline Intimate partner violence aggressor & & & & & $<0.001$ \\
\hline No & 1,163 & 94.2 & 77 & 2.7 & \\
\hline Yes & 53 & 5.8 & 9 & 16.8 & \\
\hline Intimate partner violence victim & & & & & 0.08 \\
\hline No & 1,151 & 95.3 & 80 & 7.0 & \\
\hline Yes & 65 & 4.7 & 6 & 14.6 & \\
\hline Common mental disorder** & & & & & 0.03 \\
\hline No & 880 & 72.9 & 56 & 6.1 & \\
\hline Yes & 335 & 28.1 & 30 & 10.9 & \\
\hline
\end{tabular}

*Weighted for sampling design. **No information for one subject.

*Percentuais corrigidos para desenho amostral. **Sem informação de um sujeito. 
Table 4 - Logistic regression model* for lifetime sexual abuse among female in the population sample, metropolitan São Paulo, Brazil $(n=1,206)$.

Tabela 4 - Modelo de regressão logística* para abuso sexual durante a vida entre mulheres na amostra populacional, região metropolitana de São Paulo, Brasil $(n=1.206)$.

\begin{tabular}{lccccc}
\hline & Crude OR & $95 \% \mathrm{Cl}$ & Adjusted $\mathrm{OR}^{* *}$ & $95 \% \mathrm{Cl}$ & $\mathrm{p}$-value $^{* * *}$ \\
\hline Pattern of alcohol consumption & & & & & 0.04 \\
$\quad$ Lifetime abstainer $(\mathrm{n}=618)$ & 1 & & & & \\
$1-2$ drinks $(\mathrm{n}=253)$ & 1.61 & $0.75-3.45$ & 1.68 & $0.77-3.68$ \\
$3-4$ drinks $(\mathrm{n}=73)$ & 2.41 & $0.82-7.09$ & 2.54 & $0.85-7.62$ & \\
5 drinks or more $(\mathrm{n}=44)$ & 4.87 & $1.70-13.93$ & 4.97 & $1.75-14.14$ \\
Former-drinker $(\mathrm{n}=228)$ & 2.04 & $1.11-3.75$ & 2.04 & $1.11-3.74$ & \\
\hline
\end{tabular}

*Weighted for sampling design. ${ }^{* *}$ Odds ratio adjusted for age and education as continuous variables. ${ }^{* *}$ Wald test.

*Percentuais corrigidos para desenho amostral. **Odds ratio ajustado por idade e educação como variável contínua. ***Teste de Wald.

\section{Discussion}

In this survey utilizing a stratified and representative sample of 1,216 women from metropolitan São Paulo, $7.5 \%$ women reported having suffered sexual abuse during their lives, a lower prevalence than that found in other population studies carried out in Brazil, where rates of abuse and sexual coercion at some point in life have surpassed $10 \%^{22-24}$. In international population studies, the prevalence of sexual abuse varies between $6.3 \%$ in Japan and $58.6 \%$ in Ethiopia ${ }^{22}$. The cultural heterogeneity related to sexuality demands that any comparison of results between studies should be made with caution. In the same manner, the different definitions and instruments for data collection also complicate the task of external comparison ${ }^{23}$.

In this study, lifetime sexual abuse was associated with income, although this association disappeared after multivariate analysis. Lifetime abuse was not associated with education. These data may be due to an information bias, such as the greater consciousness of women with higher education about what sets an abusive or violent sexual act. Both data contradict the findings of part of the literature that indicate low income and education as important risk factors for sexual abuse ${ }^{2}$, although the literature is not unanimous on the association with poverty or low education.

The consumption of five or more drinks was also associated with lifetime sexual abuse.
Ullman and Brecklin ${ }^{25}$ found that victims of sexual abuse who were drinking prior to assault were more likely to report that they had six or more drinks a day at least once in the past 12 months (45.1\%) compared to victims who were not drinking $(24.8 \%)$. Higher rates of alcohol intoxication episodes increase the chances of violence. Besides, as larger amounts of ethanol are consumed, higher are the chances of more severe violent acts ${ }^{13}$. Ethanol is the most frequent psychoactive substance associated with behavior's changes resulting in violence and can elevate the chances of partner violence up to five times ${ }^{6}$.

Enoch $^{26}$, in an extensive review about this issue, reported that early stress can result in many biological changes related to substance dependence.

Few general population studies in Brazil investigated sexual abuse and its relation to alcohol use. Although the prevalence of sexual abuse found in the present study was lower (7.5\%) than that found in international literature, it was similar to Bassani ${ }^{5}$ study who found $5.6 \%$ of prevalence child sexual abuse, even though they have interviewed Brazilian people from age 14. Another Brazilian studies found that in Porto Alegre city there was a prevalence of sexual abuse of $2.3 \%$ among adolescents $^{27}$, and in adults from São Paulo and Pernambuco the rates of lifetime sexual abuse were $0.2 \%$ and $1.9 \%$, respectively ${ }^{28,29}$. We submit that $7.5 \%$ is a highly expressive percentage on account of its social and 
economic impact, as well as its effect on the health system, resultant from the sexual abuse.

In the present study, lifetime sexual abuse was associated with a common mental disorder, a prevalent condition frequently related to demanding health services. In addition, the literature shows the victims of sexual abuse, rape and domestic violence are at increased risk of suicide, depression, drug and alcohol abuse, sexually transmitted diseases, hypertension, chronic pelvic pain, irritable bowel syndrome, asthma, gynecological problems, and a variety of psychiatric disorders ${ }^{30,31}$.

Some methodological limitations must be considered in the present study. First, the utilization of a few questions to identify sexual abuse can lead to underestimation of this event ${ }^{32}$. Working with the variable sexual violence in a general way, considering only the occurrence or not, without discriminating who was the perpetrator and the age at which it occurred can undermine the analysis of results. In addition, face-to-face interviews to assess difficult issues may lead the respondent to hide or minimize the fact. Thus, the projections may be underestimated, despite methodological cautions with the composition and training of the team, with privacy and security in the realization of the interview and also with the structure of the questionnaire.

Furthermore, the difficulties in studies on sexual abuse must be considered along with the invisibility of sexual coercion practiced in the domestic and/or familial sphere, which can hinder the identification of victims. Gender relations, allied with cultural values, can contribute to the minimization of sexual abuse within marriage. Considering that, culturally, the matrimonial license for sex is an almost indisputable fact, it is possible that there would be an underestimation of situations experienced in this context. These motives lead us to affirm that the prevalence of estimates of sexual abuse may be even greater than those presented herein.

\section{Conclusion}

The results of this study emphasize the important role of alcohol use and sexual abuse victimization risk, with higher risks observed for those with heavy alcohol use. Our data support the growing body of research, suggesting the need to extend screening practices to include physical and sexual abuse. Further research is needed to clarify the mechanisms through which early assaults leave women vulnerable to revictimization and to develop appropriate strategies for secondary prevention. Cross-cultural comparisons of sexual violence will help to elucidate risk groups and to create much needed prevention and intervention programs.

\section{References}

1. Vandello JA, Cohen D. Male honor and female fidelity: implicit cultural scripts that perpetuate domestic violence. J Pers Soc Psychol 2003; 84(5): 997-1010.

2. Krahé B, Bieneck S, Möller I. Understanding gender and intimate partner violence from an international perspective. Sex Roles 2005; 52(11/12): 807-27.

3. Norris F, Foster J, Weisshaar D. The epidemiology of sex differences in PTSD across developmental, societal, and research contexts. In: Kimerling R, Ouimette P, Wolfe J (eds). Gender and PTSD. New York: Guilford Press; 2002. p. 3-42.

4. Habigzang LF, Azevedo GA, Koller SH, Machado PX. Abuso sexual infantil e dinâmica familiar: Aspectos observados em processos jurídicos. Psic Teor e Pesq 2005; 21(3): 341-8.
5. Bassani DG, Palazzo LS, Béria JU, Gigante LP, Figueiredo AC, Aerts DR, et al. Child sexual abuse in southern Brazil and associated factors: a population-based study. BMC Public Health 2009; 9:133.

6. WHO - World Health Organization. Violence by intimate partners. In: Krug EG, Dahlberg LL, Mercy A, Zwi AB, Lozano R (eds). World Report on Violence and Health. Geneva: World Health Organization; 2002. p. 89-121.

7. Adeodato VG, Carvalho RR, Siqueira VR, Souza FGM. Qualidade de vida e depressão em mulheres vítimas de seus parceiros. Rev Saude Publica 2005; 39(1): 108-13.

8. Faúndes A, Hardly H, Osis MJ, Duarte GO. Risco para queixas ginecológicas e disfunções sexuais segundo história de violência sexual. Rev Bras Ginecol Obstet 2000; 22(3): 153-7. 
9. Schraiber LB, D'Oliveira AFLP. Violência contra mulheres: interfaces com a saúde. Interface - Comunic, Saúde, Educ 1999; 3(5): 11-26.

10. Zilberman ML, Blume SB. Domestic violence, alcohol and substance abuse. Rev Bras Psiquiatr 2005; 27(Suppl 2): S51-5.

11. Dunkle KL, Jewkes RK, Brown HC, Yoshihama M, Gray GE, McIntyre JA, et al. Prevalence and patterns of gender-based violence and revictimization among women attending antenatal clinics in Soweto, South Africa. Am J Epidemiol 2004; 160(3): 230-9.

12. Zaleski M, Pinsky I, Laranjeira R, Ramisetty-Mikler $\mathrm{S}$, Caetano R. Intimate partner violence and alcohol consumption. Rev Saude Publica 2010; 44(1): 53-9.

14. Widom CS, DuMont K, Czaja SJ. A prospective investigation of major depressive disorder and comorbidity in abused and neglected children grown up. Arch Gen Psychiatry 2007; 64(1): 49-56.

13. Baltieri DA. Alcohol and drug consumption and sexual impulsivity among sexual offenders [PhD dissertation]. São Paulo: Universidade de São Paulo; 2005.

15. Mac Millan HL, Fleming JE, Streiner DL, Lin E, Boyle MH, Jamieson E. Childhood abuse and lifetime psychopathology in a community sample. Am J Psychiatry 2001; 158(11): 1878-83.

16. Anda RF, Felitti VJ, Bremner JD, Walker JD, Whitfield $\mathrm{C}$, Perry BD, et al. The enduring effects of abuse and related adverse experiences in childhood. A convergence of evidence from neurobiology and epidemiology. Eur Arch Psychiatry Clin Neurosci 2006; 256(3): 174-86.

17. Roy A. Relationship of childhood trauma to age of first suicide attempt and number of attempts in substance dependent patients. Acta Psychiatry Scand 2004; 109(2): 121-5.

18. Baker CK, Norris FH, Diaz DMV, Perilla JL, Murphy AD, Hill EG. Violence and PTSD in Mexico: gender and regional differences. Soc Psychiatry Psychiatr Epidemiol 2005; 40(7): 519-28.

19. Kerr-Corrêa F, Tucci AM, Hegedus AM, Trinca LA, Oliveira JB, Feitosa TMF, et al. Drinking patterns between men and women in two distinct Brazilian communities. Rev Bras Psiquiatria 2008; 30(3): 235-42.

20. Mari JJ, Williams P. A validity study of a psychiatric screening questionnaire (SRQ-20) in primary care in the city of São Paulo. Br J Psychiatry 1986; 148: 23-6.
21. Rao JNK, Scott AJ. On Chi-squared tests for multiway contingency tables with cell proportions estimated from survey data. Annals of Statistics 1984; 12(1): 46-60.

22. Garcia-Moreno C, Heise L, Jansen HAFM, Ellsberg M, Heise $\mathrm{L}$, Charlotte $\mathrm{H}$, et al. Prevalence of intimate partner violence: findings from the WHO multi-country study on women's health and domestic violence. Lancet 2006; 368(9543): 1260-9.

23. Moraes CL, Cabral CS, Heilborn ML. Magnitude e caracterização de coerção sexual vivenciadas por jovens de três grandes capitais brasileiras: Porto Alegre, Rio de Janeiro e Salvador. Cad Saúde Pública 2006; 22(7): 1493-504.

24. Schraiber LB, D'Oliveira AFPL, França-Jr I. Violência sexual por parceiro íntimo entre homens e mulheres no Brasil urbano, 2005. Rev Saude Publica 2008;42(Suppl 1):127-37.

25. Ullman SE, Brecklin LR. Alcohol and adult sexual assault in a national sample of women. J Subst Abuse 2000; 11(4): 405-20.

26. Enoch MA. The role of early life stress as a predictor for alcohol and drug dependence. Psychopharmacology 2011; 214(1): 17-21.

27. Polanczyk GV, Zavaschi ML, Benetti S, Zenker R, Gammerman PW. Violência sexual e sua prevalência em adolescentes de Porto Alegre, Brasil. Rev Saude Publica 2003; 37(1): 8-14.

28. Ludemir AB, Schraiber LB, D’Oliveira AFPL, França-Jr I, Jansen HA. Violence against women by their intimate partner and common mental disorders. Soc Sci Med 2008; 66(4): 1008-18.

29. Schraiber LB, D'Oliveira AFPL, França-Jr I, Diniz CSG, Portella AP, Ludermir AB, et al. Prevalência da violência contra a mulher por parceiro íntimo em regiões do Brasil. Rev Saude Publica 2007; 41(5): 797-807.

30. Heise L. Violência e gênero: uma epidemia global. Cad Saúde Pública 1994; 10(Supl. 1): 135-45.

31. Tucci AM, Kerr-Corrêa F, Souza-Formigoni MLO. Childhood trauma in substance use disorder and depression: An analysis by gender among a Brazilian clinical sample. Child Abus Negl 2010; 34(2): 95-104.

32. Nunnally JCJ, Bernstein I. Psychometric theory. New York: McGraw-Hill; 1995.

Received on: $02 / 25 / 13$

Final version presented on: 08/05/13 Accepted on: 09/13/13 